\title{
PEMBELAJARAN BERBASIS MASALAH EKOWISATA PADA MATA PELAJARAN EKONOMI SMA
}

\author{
Kiromim Baroroh \\ Universitas Negeri Yogyakarta \\ kiromim_b@uny.ac.id
}

\begin{abstract}
Abstrak: Penulisan kajian ini mempunyai tujuan: 1) mengidentifikasi permasalahan ekowisata, 2) mengetahui Model Pengembangan Ekowisata Berkelanjutan, dan 3) Mengetahui tahap pembelajaran berbasis masalah dalam pembelajaran ekonomi. Kajian literatur ini menggunakan metode narrative review dan descriptive review. Hasil dari kajian ini adalah: 1) permasalahan ekowisata yaitu: a) pelanggaran konservasi, b) Rendahnya partisipasi masyarakat dalam Ekowisata, c) Pengelolaan yang salah, d) Kurang pelibatan lembaga pendidikan formal di sekitar sekolah; 2) Model pengembangan ekowisata berkelanjutan yang disusun berdasarkan: a) visi dan tujuan utama pola pengembangan serta pengelolaan wisata adalah pembangunan berkelanjutan; b) Elemen Produk Pariwisata berbentuk wisata yang berbasis masyarakat, c) Memiliki pilar pelestarian lingkungan, pendidikan berbasis partisipasi, pengayaan atraksi, pelestarian budaya, keeratan masyarakat, dan pemberdayaan ekonomi masyarakat lokal d) mendapat dukungan penuh oleh seluruh pemangku kepentingan; 3) pembelajaran berbasis masalah dalam pembelajaran ekonomi di kelas meliputi tahap: a) merumuskan masalah ekowisata, b) menelaah masalah ekowisata, c) merumuskan hipotesis ekowisata, d) mengumpulkan data tentang ekowisata e) membuktikan hipotesis, f) Menentukan pilihan penyelesaian masalah ekowisata. Ekowisata dapat menjadi sumber belajar peserta didik secara langsung maupun tidak langsung.
\end{abstract}

Kata kunci: Ekowisata, Mata Pelajaran ekonomi, Sekolah Menengah Atas

\section{LEARNING BASED ON ECOTOURISM PROBLEMS IN ECONOMIC SUBJECTS IN HIGH SCHOOLS}

\begin{abstract}
The writing of this study aims: 1) to identify the problem of ecotourism, 2) to know the Model of Sustainable Ecotourism Development, and 3) To identify the stage of problem-based learning in economic learning. This research is a literature review using a narrative review and descriptive review methods. The results of this study are: 1) ecotourism issues, namely: a) conservation violations, b) low community participation in ecotourism, c) mismanagement, d) lack of involvement of formal educational institutions around schools; 2) Sustainable Ecotourism Development Model based on four elements, namely; a) Making the issue of Sustainable Development the central vision and objective of the pattern of tourism development and management; b) In the form of communitybased tourism as an Element of Tourism Products, c) Having pillars of environmental preservation, cultural preservation, enrichment of attractions, participation-based education, community closeness, and economic empowerment of local communities as Criteria Element, d) Fully supported by all stakeholders; 3) problem-based learning in economic learning in class includes the stages: a) Formulating the problem of ecotourism, b) Analyzing the problem of ecotourism, c) Formulating a hypothesis of ecotourism, d) Collecting data of ecotourism, e) Proving the hypothesis, f) Determining the choice of resolution . Ecotourism can be a source of student learning, both directly and indirectly.
\end{abstract}

Key Words: Ecotourism, Economic Subjects, Senior High School

\section{PENDAHULUAN}

Perkembangan teknologi informasi dan pengaruh globalisasi yang terus terjadi, menuntut manusia beradaptasi dengan lingkungan yang berubah pula. Dunia pendidikan perlu menyiapkan peserta didik menghadapi perubahan tersebut. Hal itu menjadi tantangan bagi dunia pendidikan untuk membersamai peserta didik mengenal zamannya. Pendidikan yang diterima peserta didik perlu 
dipastikan telah dilengkapi dengan keterampilan yang dapat ditranfer dalam kehidupan sosial dan ekonomi yang ikut berubah seiring perubahan zaman tersebut.

Saat ini sekolah di Indonesia menggunakan kurikulum 2013. Dalam kurikulum tersebut, setiap peserta didik diharapkan menguasai empat kompetensi inti (KI) setelah mengikuti pembelajaran, yaitu: 1) kompetensi sikap spiritual, 2) sikap sosial, 3) pengetahuan, dan 4) keterampilan (Sutjipto. 2016: 239). Kompetensi inti ditumbuhkembangkan melalui beberapa proses pembelajaran, yaitu: intrakurikuler, kokurikuler, dan/ atau ekstrakurikuler.

Pada pendidikan konvensional, proses pendidikan hanya menitikberatkan dalam segi pengetahuan (kognitif) saja sedangkan segi sikap hanya mendapat porsi yang sangat sedikit (Haryadi, Toto \& Aripin. 2015: 40). Padahal pembentukan sikap peserta didik merupakan kompetensi yang harus dimiliki oleh peserta didik. Oleh sebab itu, pembentukan sikap tersebut dapat dikatakan sangat penting dalam proses pembelajaran (Zahroh, Fatim. 2017). Pembentukan kompetensi sikap tersebut dilakukan sepanjang proses pembelajaran berlangsung. Ini menjadi pertimbangan guru dalam mengembangkan karakter peserta didik lebih lanjut.

Pembelajaran model pemecahan masalah yang berdasarkan lingkungannya, dapat menanamkan berpikir kritis peserta didik dalam menjaga dan mengembangkan lingkungan. Setiap lingkungan peserta didik berpotensi menjadi industri pariwisata. Terbukti semakin bermunculan destinasi pariwisata yang dikembangkan oleh masyarakat. Misalnya, jumlah desa wisata di Yogyakarta terus bertambah dari 80 pada tahun 2014 meningkat menjadi 112 pada tahun 2015 (Poerwanto, Endy. 2016). Pariwisata diposisikan sebagai salah satu sektor vital dalam pembangunan ekonomi Indonesia. Saat ini dan pada masa yang akan datang, pariwisata diharapkan dapat memberikan kontribusi terbesar terhadap peningkatan devisa negara. Pariwsiata diharapkan menjadi pengungkit kesejahteraan dan kemakmuran rakyat. Penggerak sektor pariwisata terus berupaya untuk meningkatkan kinerja dengan memperkuat jejaring yang telah tercipta di satu sisi, dan meningkatkan daya saing usaha pariwisata di Indonesia pada sisi yang lain (Haryanto, Joko Tri. 2014: 276).

Pariwisata saat ini cenderung beralih pada konsep pembangunan pariwisata berkelanjutan dengan mengembangkan konsep ekowisata. Konsep ekowisata merupakan bentuk perjalanan wisata ke lingkungan alam yang bertujuan untuk menjaga kelestarian alam, tanpa melakukan kegiatan merusak (Fandeli, C. 2000). Ekowisata merupakan gabungan kepentingan yang muncul dari keperdulian terhadap masalah lingkungan, ekonomi dan sosial. Poin utama dalam ekowisata adalah menciptakan devisa masuk kembali ke negara, sehingga kerugian akibat pariwsiata dapat dipulihkan melalui konservasi alam dengan pembiayaan sendiri, sehingga ini pun menjadi inti dari cabang ilmu ekonomi hijau yaitu pembangunan berkelanjutan (Haryanto, Joko Tri. 2014: 278).

Pariwisata dipandang berkontribusi pada kesejahteraan penduduk dunia. Namun di sisi lain, pembangunan pariwisata juga sering disebut sebagai salah satu penyebab utama kerusakan lingkungan. Menurut laporan World Tourism Organization tahun 1996, pembangunan infrastruktur pariwisata tanpa mempedulikan kelestarian alam menyebabkan alih fungsi lahan. Pembangunan fasilitas pariwisata seperti resort, hotel, restoran yang tanpa terkendali dapat merusak kelestarian lingkungan. Flora yang dilindungipun harus ditebang demi mewujudkan infrasrtukut yang memadai. Fauna pun merasa terusik dengan keramaian wisatawan yang menyebabkan perilaku agresif pada manusia. Masuknya budaya asing yang bertentangan dengan norma adat masyarakat lokal menyebabkan bergesernya tatanan sosial dan perubahan nilai budaya lokal. (Satria, Dias. 2009:40). Dapat dikatakan bahwa perkembangan sektor pariwista tersebut memiliki dampak positif dan negatif sehingga memerlukan strategi untuk pengelolaannya. 
Pengelolaan desa wisata hendaklah didukung oleh lembaga formal dalam pembelajaran di sekolah, salah satunya pembelajaran ekonomi. Pembelajaran ekonomi masih sering menggunakan komunikasi satu arah dan kurang kontektual (Yulianto, A., \& Yulianto, A. 2006: 143). Pembelajaran masih terpisah dengan keadaan lingkungan sekitar. Saat ini, hampir di setiap kabupaten memiliki desa wisata. Seperti yang diungkapkan sebelumnya bahwa desa wisata memiliki dampak ganda maka potensi desa wisata sebagai ekowisata ini layak menjadi sumber belajar dalam pembelajaran ekonomi di SMA. Sekolah di sekitar lokasi wisata perlu dilibatkan dalam kegiatan pelestarian daerah wisata ini, sehigga pembangunan ekowisata berkelanjutan dapat diwujudkan. Peserta didik dilibatkan dalam pengembangan desa wisata agar dapat berfikir kritis dan dapat mengenali masalah yang ada sekaligus mencoba menyelesaikan permasalahan di lokasi tersebut. Maka tujuan penulisan artikel ini adalah untuk mengidentifikasi permasalahan ekowisata, mengetahui model pengembangan ekowisata berkelanjutan, dan tahap pembelajaran berbasis masalah dalam pembelajaran ekonomi SMA.

\section{METODE}

Penelitian ini adalah kajian literatur (literature review) yang menggunakan metode narrative review dan descriptive review (Yudhiyati, Ratna. 2020: 62). Kajian literatur yang menggunakan metode narrative review biasanya mengelompokkan objek penelitian berdasarkan metode penelitian, tema, atau hasil penelitian untuk kemudian dijabarkan dalam bentuk narasi. Descriptive review lebih bersifat kuantitatif dibandingkan narrative review dimana penelitian yang menggunakan metode ini biasanya melakukan kodifikasi terhadap objek penelitian berdasarkan waktu publikasi, metodologi, teori, atau hasil, untuk kemudian melakukan analisis frekuensi terhadap hasil kodifikasi tersebut.

\section{HASIL DAN PEMBAHASAN}

\section{Permasalahan Ekowisata}

Ekowisata/ eko dan turisme/ eko wisata berakar dari dua kata yaitu eko yang berarti rumah dan tourism berarti wisata/perjalanan (Boedirachminarni, A., \& Suliswanto, S. W. 2017: 107). Kata Prosiding Seminar Nasional Pariwisata Hijau Dan Pengembangan Ekonomi "Green Tourism And Economic Development" memunculkan kata Eco dapat diartikan sebagai Ekologi atau Economi, sehingga berdasarkan dua kata tersebut akan muncul Wisata ekologis (Ecological Tourism) atau Wisata Ekonomi (Economic Tourism). Kedua diksi ini masih menjadi perdebatan yang menarik hingga saat ini.

Ekowisata adalah kegiatan wisata ke suatu lingkungan yang masih alami maupun buatan guna menikmati pemandangan dan budaya yang bersifat informatif dan partisipatif, bertujuan menjamin kelestarian alam dan sosial-budaya, ekowisata dapat berperan dalam menuntaskan permasalahan pengembangan kawasan pariwisata (Haryanto, Joko Tri. 2014: 280). Senada dengan Haryanto dan Satria, tokoh lain memberikan definisi ekowisata sebagai bentuk kegiatan perjalanan wisata yang bertanggung jawab ke kawasan alami dengan tujuan mengkonservasi lingkungan, melestarikan kehidupan serta kesejahteraan penduduk lokal (Hermansyah, H., \& Sunaryo, B. 2016: 3). Harus ada integrasi yang seimbang antara menikmati keindahan alam dan upaya mempertahankan kelestarian alam (Boedirachminarni, A., \& Suliswanto, S. W. 2013: 107).

Tiga hal pokok dalam ekowisata yaitu; keberlangsungan alam/ekologi, kebermanfaatan ekonomi, dan keberterimaan dalam kehidupan sosial masyarakat (Satria, Dias. 2009: 39). Ekowisata memberikan konsep pembangunan pariwsiata berkelanjutan dan memberikan peran 
aktif yang lebih besar pada masyarakat lokal sebagai pengelola utama (Satria, Dias. 2009: 39). Masyarakat umum dapat memiliki akses untuk menikmati, mengetaui, menyaksikan, merasakan pengalaman intelektual, alam, dan adat istiadat masyarakat setempat. Dengan demikian konsep ekowisata adalah konsep yang menekankan adanya pengeloaan wisata untuk kepentingan ekonomi dan sosial yang mengutamakan kelestarian lingkungan yang melibatkan partisipasi masyarakat lokal.

Desa wisata yang berkonsep ekowisata dewasa ini semakin berkembang karena kemudahan akses terhadap media sosial melalui ineternet. Permintaan wisatawan akan selalu mengalami perubahan. Perminatan ini disebabkan oleh empat faktor yaitu: 1) Wistawan semakin bosan dengan produk yang bersifat masal dan homogen; 2) wisatawan kesadaran terhadap kelestarian lingkungan dan budaya semakin meningkat; 3) wisatawan memiliki kesadaran eksploitasi berlebihan terhadap lingkungan alam dan budaya akan mengganggu kelestarian lingkungan alam dan budaya; dan 4) sikap pelaku pariwisata dan tour operator mengalami perubahan ke arah yang lebih baik (Awang, dkk. 2012: 29).

Stakeholder pariwisata semakin meyakini bahwa apabila menginginkan dunia pariwisata memberikan kesejahteraan dan keuntungan sosial ekonomi yang lebih tinggi maka hendaklah mulai menjadikan pengelolaan pariwisata yang berkelanjutan sebagai alternative (Awang, dkk. 2012:29). Maka upaya untuk mencari alternative ini dapat dilakukan oleh berbagai pihak, satu diantaranya adalah melalui pendidikan SMA. Siswa SMA hendaklah diajarkan mengenai pergeseran konsep kepariwisataan dunia kearah pariwisata berbasis alam dan budaya penduduk lokal (Fandeli, C. 2000). Fakta ini merupakan peluang besar bagi negara Indonesia dengan potensi alam yang luar biasa (Boedirachminarni, A., \& Suliswanto, S. W. 2013: 107). Pergeseran konsep kepariwisataan dunia kepada ekowisata, merupakan sebuah peluang dan tantangan besar bagi negara Indonesia yang kaya potensi alam dan budaya.

Green Tourism Association mengemukakan pengertian ekowisata sebagai pembangunan pariwisata yang memiliki empat pilar (atribut) yaitu; a) Environmental responsibility; memberikan konservasi dan proteksi lingkungan alam dan fisik yang memberikan jaminan ekosistem yang terjaga kelestariannya. Contoh Ujung Kulon terkenal memiliki panorama alam yang mendukung pelestarian satwa badak bercula; b) Local economic vitality; menumbuhkembangkan sumber ekonomi komunitas lokal. Hal ini akan menjadi kekuatan bisnis dan komunitas yang berkelanjutan. Misalnya pembangunan lokasi wisata akan mendorong berkembangnya ekonomi lokal. Contoh kegiatan ekonomi lokal adalah obyek Desa Wisata Wisata Tembi yang berhasil memberdayakan potensi ekonomi lokal dengan adanya homestay Griya Kayana, yang dikelola oleh masyarakat lokal. Berdasarkan wawancara dengan pemilik Griya Kayana yaitu Ibu Nelva diperoleh informasi adanya desa wisata ini dapat meningkatkan hunian di homestaynya. Dia juga mempekerjakan tetangga sebagai koki; c) Cultural sensitivity; adanya kecenderungan untuk menghormati dan mengapresiasi adat istiadat dan berbagai budaya masyarakat lokal. Contoh pada kegiatan budaya wisatawan akan mengenal budaya lokal dengan lebih baik yang pada akhirnya akan timbul toleransi dan penghormatan kepada budaya tersebut.; d) Experiental richness; wisatawan dapat terlibat dalam berbagai kegiatan alam dan budaya yang pada akhirnya akan memberikan pengalaman dan wawasan yang lebih baik. (Haryanto, Joko Tri. 2014: 284).

Banyak nilai positif dalam konsep ekowisata, namun bukan berarti tanpa persoalan dan kritik pada pelaksanaanya di lapangan. Beberapa masalah terhadap konsep ekowisata antara lain: Pertama, pelanggaran terhadap lingkungan masih terjadi di lapangan meskipun isu konservasi menjadi agenda utama. Hal disebabkan karena: 1) kesadaran dan pengetahuan masyarakat sekitar serta wisatawan tentang konsep ekowisata masih rendah, 2) manajemen dan peran pemerintah 
masih lemah dalam mendorong upaya konservasi. Pemerintah juga belum melakukan tindakan tegas dalam rangka menghukum para perusak lingkungan.

Kedua, partisipasi masyarakat yang rendah dalam pengelolaan Ekowisata. Peran masyarakat lokal sebagai stakeholder sering terlupakan, padahal partisipasi mereka sangat menentukan dalam pertumbuhan kawasan wisata (Setiawan, D. 2020: 325). Masyarakat sekitar seringkali hanya menjadi obyek/penonton pada kegiatan ekowisata. Mereka tidak terlibat aktif dalam setiap proses ekonomi di daerah wisata. Misalnya ekowisata B yang ternyata lebih banyak dikelola oleh investor asing, bahkan ada pulau pribadi yang dimiliki oleh individu.

Ketiga, manajemen yang salah. Rendahnaya pemahaman terhadap konsep ekowisata menyebabkan manajemen yang salah pula (Satria, Dias. 2009: 40). Konsep ekowisata dapat diperluas menjadi konsep ekowista yang luas. Sebagai contoh wisata bahari tidak hanya berhenti pada pengembangan potensi laut, namun dapat diperluas menjadi konsep wisata alam, sejarah, budaya, dan keunikan komunitas. Kegiatan yang dapat dikembangkan berperahu, berenang, memancing, kuliner, bahkan wisata sejarah dan pendidikan berupa penanaman mangrove.

Keempat, kurang pelibatan lembaga pendidikan formal di sekitar sekolah. Sekolah merupakan salah satu lembaga formal yang ada di sekitar desa wisata yang mnerapkan ekowisata, namun terkadang keberadaannya diabaikan dalam pengembangan desa wisata. Demikian pula terkadang sekolah abai dalam pengelolan desa wisata di sekitar sekolah. Padahal sekolah dan lingkungan dapat bersinergi dalam meningkatkan kualitas pembelajaran dan meningkatkan kualitas desa wisata. Ekowisata yang dikembangkan desa wisata dapat menjadi sebagai salah satu sumber belajar di sekolah formal. Demikian pula peserta didik dapat menjadi subyek dalam mengembangkan desa wisata, supaya mereka dapat berkontribusi dalam mengembangkan desa wisata tersebut.

\section{Model Pengembangan Ekowisata Berkelanjutan}

Dari berbagai permasalahan yang ada maka perlu solusi dari berbagai permasalah tersebut menggunakan strategi pembelajan berbasis masalah yang ada di daerah ekowisata. Haryanto menyusun model pengembangan ekowisata berkelanjutan, sebagai berikut 1) elemen utama pariwisata adalah perbaikan perundang-undangan dan penegakan sangsi bagi pelanggar ekowisata di lapangan 2) elemen produk pariwisata. Menempatkan masyarakat sebagai aktor utama pembangunan pariwisata; 3) elemen kriteria meliputi pemilikan pilar pelestarian lingkungan dan budaya, penganekaragaman atraksi, pendidikan berbasis partisipasi, persatuan masyarakat, dan pemberdayaan ekonomi masyarakat lokal. Ketika ada kesalahan salah satu elemen akan segera diperbaiki; dan 4) elemen Pendukung, dukungan penuh datang dari seluruh stakeholders yaitu masyarakat sekitar, pengunjung, pengelola, sekolah, perguruan tinggi, pemerintah daerah pemerintah pusat, maupun pengusaha pariwisata. (Haryanto, Joko Tri. 2014: 284): 1) Pendidikan formal hendaklah dilibatkan dalam kegiatan ini. Peserta didik hendaklah dikenalkan sejak dari bangku sekolah.

Sekolah sebagai komponen penting dalam menyiapkan warga negara yang bertanggung jawab juga memiliki tugas untuk memberikan solusi atas masalah yang ada melalui pembelajaran. salah satu strategi pembelajaran yang disusun adalah pembelajaran berbasis masalah di desa yang menjalankan Ekowisata. Wujud strategi ini adalah dalam pembuatan skenario pembelajaran yang akan dipraktikkan di sekolah. 


\section{Tahap Pembelajaran Berbasis Masalah dalam Pembelajaran Ekonomi SMA}

Kurikulum SMA mencantumkan ekonomi sebagai salah satu mata pelajaran yang dipelajari oleh peserta didik. Ilmu ekonomi merupakan studi mengenai upaya individu/masyarakat dalam rangka memilih alternative sumber ekonomi yang paling tepat dengan menggunakan uang atau tanpa uang dalam rangka memanfaatkan sumber ekonomi prroduktif yang langka dalam kegiatan produksi, distribusi, dan konsumsi pada waktu sekarang dan yang akan datang kepada individu maupun kelompok masyarakat. (Samuelson, 1976:3; Rosyidi, S. 2011: 9)

Sebagai ilmu sosial, ekonomi sering dipelajari bersama disiplin ilmu lain, seperti sosiologi, antropologi, politik, dan psikologi, serta bidang bisnis, akuntansi, dan keuangan. Pengajaran ilmu ekonomi didasarkan pada model analitis yang membutuhkan pemahaman matematika yang tingi, di masa lalu bidang itu lebih diskursif dan berbasis teks (Fry, H., Ketteridge, S., dan Marshall, S. 2013: 499). Dengan demikian ilmu ekonomi dapat mengggunanakan lingkungan sekitar serta kasus terkait ekonomi yang ada di media massa.

Belajar ilmu ekonomi tentunya memberikan manfaat yang besar bagi peserta didik. Adapun manfaat tersebut adalah: 1) Ilmu ekonomi memberikan bantuan peserta didik dalam menggunakan pertimbangan ekonomis yang terjadi di sekitar mereka maupun di luar jangkauan kemampuan mereka; 2) Ilmu ekonomi memberikan bantuan peserta didik dalam mengumpulkan informasi. Peserta didik dapat terdorong untuk memperluas pengetahuan dan wawasannya; dan 3) Ilmu ekonomi membentuk peserta didik memiliki sikap bertanggung jawab dan bijak, rasional. Peserta didik akan memiliki pengetahuan dan keterampilan ilmu ekonomi, akuntansi dan manajemen yang berguna bagi dirinya, orang lain, rumah tangga, dan negara (Rosyidi, S. 2011: 35-38).

Pembelajaran ekonomi pada hakikatnya merupakan interaksi antara peserta didik dengan sumber belajar yang akan menyebabkan perubahan tingkah laku ke arah yang lebih baik. Guru hendaklah dapat memfasilitasi antara peserta didik dengan sumber belajar di sekitarnya. Proses pembelajaran hendaklah didesain dengan menarik dan kontekstual sehingga menciptakan rasa ingin tahu peserta didik.

Proses pembelajaran ekonomi merupakan suatu bentuk penyelenggaran mata pelajaran ekonomi yang memadukan komponen pembelajaran secara sistematis dan berkesinambungan dalam kegiatan pendidikan di lingkungan sekolah maupun luar sekolah. Komponen guru, peserta didik, kurikulum, dan sumber belajar harus saling terpadu. Hal ini dilakukan untuk memperoleh pengalaman belajar bagi seluruh peserta didik. Pengalaman belajar ini akan memberikan kesempatan pada peserta didik untuk mengesplorasi kemampuan dirinya. Peserta didik dapat aktif membangun gagasan dan menmbangun pengetahuan dimanpun, di perpustakaan, laboratorium, pasar, bank, lingkungan sekitar ataupun di tempat rekreasi.

Peserta didik dapat diajak untuk mengkonstruk gagasan dan mengembangkan pola pikir agar tumbuh secara optimal. Peserta didik dapat memberikan apresiasi dan penilaian terhadap lingkungan sosial ekonomi. Lingungan sekitar ini adalah bentuk yang nyata dari teori yang cenderung bersifat abstrak. Metode pembelajaran yang sesuai materi dan karakteristik peserta didik akan membantu tercapainya tujuan pembelajaran ekonomi. Sehingga kemampuan guru yang berkualitas sangat membantu penguasaan kompetensi peserta didik.

Ketika pembelajaran ekonomi berlangsung di sekolah, pengantar ekonomi selalu didasarkan pada pendekatan "bata bangunan" (Fry, H., Ketteridge, S., dan Marshall, S. 2013). Pendekatan ini mengajak peserta didik melalui urutan langkah-langkah yang masuk akal untuk membangun pemahaman teoritis mereka. Sifat berurutan pelajaran ini dapat mengarah pada pendekatan ceramah yang memberikan terlalu banyak perhatian pada masing-masing langkah sehingga 
gambaran yang lebih kompleks terlewatkan. Guru mengetahui apa yang menjadi tujuan pembelajaran, namun terkadang terlewatkan. Secara sederhana yang dapat dijadikan panduan di sini adalah guru harus memastikan bahawa pembelajaran harus dimulai dari gambaran komplek, menetapkan langkah-langkah tertentu yang harus dicapaidalam konteks yang lebih luas, dan menghubungkankan kembali langkah yang sudah dilakukan dan berlanjut ke langkah berikutnya.bagi guru mungkin langkah ini sudah jelas, namun apa yang jelas bagi guru belum tentu jelas bagi peserta didik.

Ketika mengajar, guru sering mengunakan power point. Banyak guru yang memasukkan gaya yang beraneka ragam untuk penjelasan teks, grafis, aljabar, dan matematis. Namun ciri-ciri pokok visual yang efektif dalam ekonomi yaitu kesederhanaan, akurasi dan fleksibilitas (Fry, H., Ketteridge, S., dan Marshall, S. 2013: 502). Slide yang sederhana adalah slide yang mempunyai tampilan simple, namun dapat mengungkap maksud dari guru. Ketika akan mengungkap tentang jumlah pengangguran di Indonesia, slide data BPS dapat dituliskan dengan penonjolan pada angka. Jangan terlalu menggunakan banyak kata yang terkadang justru tidak bermanfaat.

Akurasi dalam slide menunjukkan data/deskripsi yang tepat. Slide juga harus disesuaikan dengan materi dan karakter peserta didik. Peserta didik terutama SMA dan SMP mempunyai selera warna yang lebih terang sesuai gaya remaja. Akurasi juga terkait dengan notasi matematika. Banyak buku teks yang menuliskan notasi yang berbeda untuk satu variabel yang sama, misalnya harga dan jumlah barang dinotasikan (P dan $\mathrm{Q}$ ), mungkin di buku lain menggunakan notasi yang berbeda. Sehingga guru harus memastikan notasi yangdimaksud dalam slide tersebut, jangan sampai ini membuat peserta didik bingung. Slide yang fleksibel perlu dalam pembelajaran. Slide yang dituliskan oleh guru merupakan slide dasar untuk mengajak peserta didik berfikir lebih dalam tentang materi pembelajaran yang dihadapi. Slide ini fleksibel untuk mengembangkan masalah di dalam kelas. Slide dapat di padu padankan dnegan menggunakan media lain seperti papan tulis. Untuk materi yang membutuhkan hitungan dan kurva, penggunaan papan tulis masih dibutuhkan. Ini untuk mengoptimalkan daya tangkap peserta didik.

Sumber belajar merupakan serangkaian informasi yang terseimpan dalam berbagai media yang dapat membantu peserta didik dalam kegiatan belajar yang merupakan bagian perwujudan kurikulum. Pengkategorian sumber belajar adalah sebagai berikut: 1) tempat/lingkungan yang dapat memberikan inspirasi kepada peserta didik untuk terlibat dalam proses perubahan ingkah laku. Misalnya lingkungan alam (gunung, pantai,), lingkungan buatan (pasar, museum, Tempat Pembuangan sampah, desa wisata). 2) Benda yang dapat memberikan kemungkinan perubahan tingkah laku pada peserta didik. Misalnya candi akan memberikan perubahan persepsi peserta didik untuk lebih menghargai hasil karya nenek moyang dan meningkatkan sikap nasionalisme, pasar akan memberikan pemahaman tentang permintaan dan penawaran. 3) Orang yaitu individu/kelompok individu yang yang memiliki keahlian/keterampilan tertentu yang memberikan pengetahuan/keterampikan kepada peserta didik, maka yang bersangkutan dapat dikategorikan sebagai sumber belajar. Misalnya, guru, ahli geologi, polisi, petani, peternak, pengelola desa wisata dan ahli lainnya 5) Peristiwa dan fakta di lapangan misalnya adanya jual beli saham, peristiwa bencana alam, peristiwa pengembangan ekowisata dan peristiwa lainnya (Majid, Abdul. 2005: 170).

Penumbuhan dan pengembangan kompetensi dilakukan sepanjang proses pembelajaran berlangsung. Guru dapat mengembangkan karakter peserta didik lebih intensif. Pembelajaran model pemecahan masalah yang berdasarkan lingkungannya, dapat menanamkan berpikir kritis peserta didik dalam menjaga dan mengembangkan lingkungan. Terdapat kemiripan dalam istilah inquiry, discovery, dan problem solving. Istilah sesungguhnya merupakan sebuah metode mengajar 
yang sifatnya mencari secara logis, kritis, analitis menuju sebuah kesimpulan. Titik tekan pada metode problem solving ini, adalah pada kemampuan memecahkan permasalahan secara logis, rasional, dan tepat (Hidayati. 2014:3). W. Gulo (2002) memberikan pengertian pembelajaran pemecahan masalah adalah strategi pembelajaran pada proses pemikiran serta mencari jalan keluar bagi sebuah permasalahan.

Kesimpulan yang dapat diambil adalah pembelajaran pemecahan masalah (problem solving) merupakan kegiatan belajar yang melibatkan peserta didik aktif dalam pembelajaran. Pembelajaran diawali dengan masalah yang dapat berasal dari guru/peserta didik, selanjutnya peserta didik sendiri yang mengkonstruk masalah itu dan mencari solusi terbaik dari masalah itu berdasarkan berbagai sumber belajar. Dalam kegiatan belajar ini peserta didik aktif berfikir, berdiskusi, dan mencari sumber belajar untuk memecahkan masalah. Peserta didik dapat mengerjakan secara individual maupun berkelompok.

Dalam pembelajaran berbasis masalah, terdapat dua aspek yang mendasari proses pembelajaran pemecahan masalah, yaitu: 1) Aspek psikologi. Secara psikologis kita meyakini bahwa setiap peserta didik ketika akan memulai pembelajaran bukan berada dalam kondisi kosong pengetahuan. Mereka sudah memiliki bekal pengetahuan dan pengalaman sebelumnya. Proses belajar tidak hanya proses hafalan fakta di luar kepala, terjadi kesadaran peserta didik untuk melakukan interaksi dengan individu lain dan dengan lingkungannya, sehingga aspek psikologi peserta didik akan berkembang secara utuh. Perkembangan aspek kognitif, afektif dan psikomotor akan berkembang dengan sempurna; 2) Aspek Filosofis. Kita menyadari pendidikan di sekolah adalah awal peserta didik belajar untuk menjadi manusia seutuhnya, sekolah merupakan tempat peserta didik memecahkan masalah supaya mereka siap ketika terjun di masyarakat (Sanjaya, Wina. 2010:213).

Strategi pemecahan masalah dapat digunakan untuk memperbaiki sistem pembelajaran agar lebih berkualitas. Ada tiga ciri utama dalam pembelajaran pemecahan masalah, yaitu: pertama, terdapat rangkaian aktivitas pembelajaran yang tidak dapat dipisahkan. peserta didik menjalankan serangkaian kegiatan yang harus dikerjakan. Peserta didik aktif berfikir, berkomunikasi dengan guru, siswa lain dan lingkungan. Peserta didik aktif mencari dan mengolah data yang tersaji di dalam sumber belajar. Kedua, kegiatan pembelajaran diarahkan untuk menyelesaikan masalah, sehingga guru harus pandai-pandai mengarahkan peserta didik agar dapat menemukan masalah. Ketiga, memanfaatkan pendekatan berfikir ilmiah yang dilakukan secara empiris dan sistematis (Sanjaya, Wina. 2010:214-215). Pembelajaran pemecahan masalah berbeda dengan pembelajaran lainnya, dalam pembelajaran pemecahan masalah (problem solving) memberikan kesempatan pada peserta didik untuk mengembankan kememapuannya dalam mengumpulkan dan menganalisis data secara lengkap dalam memecahkan masalah yang dihadapi. Penyelesaian masalah dilakukan secara ilmiah atau semi ilmiah. Guna mendukung strategi pemecahan masalah, guru hendaklah pandai dalam menyiapkan bahan pelajaran yang memiliki permasalahan yang menarik untuk dikaji. Materi pelajaran tidak hanya terbatas pada buku referensi, tetapi juga dari sumber lingkungan seperti peristiwa di masyarakat/di lingkungan sekolah.

Ada anggota masyarakat yang menyatakan bahwa pembelajaran di kelas hanya sebatas teori dan sulit terapkan di kehidupan nyata. Hal tersebut didasari oleh masalah yang ada ditengah masyarakat selalu dinamis sehingga apabila pembelajaran yang dilakukan hanya melalui buku tentu akan muncul kesenjangan. Maka materi pelajaran yang digunakan dalam pembelajaran tidak hanya pada buku sumber tetapi dari peristiwa-peristiwa yang nyata terjadi di lingkungan sekitar sesuai dengan kurikulum yang berlaku. Kriteria dalam pemilihan bahan ajar yang tepat, yaitu: 1) Bahan yang dipilih hendaklah bersifat conflict issue atau kontroversial. Bahan ajar audio 
video dapat merekam peristiwa penting dalam masyarakat. Bahan ajar dari koran/majalah/website dapat dimanfaatkan untuk pembelajaran; 2) Bahan hendaklah bersifat umum sehingga peserta didik tidak merasa asing; 3) Bahan menampilkan kepentingan orang banyak dalam masyarakat; 4) Bahan ajar sesuai dengan tujuan pengajaran serta pokok bahasan yang termuat dalam kurikulum sekolah; 5) Bahan tersebut hendaklah mampu merangsang perkembangan peserta didik yang mengarah pada tujuan pembelajaran(Maryati, Iyam. 2018: 66).

Pembelajaran berbasis masalah dalam pembelajaran ekonomi tersebut harus mempertimbangkan langkah-langkah pemecahan masalah. Langkah-langkah pemecahan masalah menurut John Dawey dalam W.Gulo (2002) meliputi beberapa tahapan sebagai berikut:

Tabel 1. Tahap-tahap Pembelajaran Pemecahan Masalah

\begin{tabular}{|c|c|}
\hline Tahap-tahap & Kemampuan yang diperlukan \\
\hline Merumuskan masalah & $\begin{array}{l}\text { Peserta didik mampu mengetahui dan } \\
\text { merumuskan masalah secara jelas }\end{array}$ \\
\hline Menelaah masalah & $\begin{array}{l}\text { Peserta didik mampu menggunakan } \\
\text { pengetahuan untuk memperinci, menganalisis } \\
\text { masalah dari berbagai sudut pandang }\end{array}$ \\
\hline Merumuskan hipotesis & $\begin{array}{l}\text { Peserta didik mampu menyusun dugaan } \\
\text { sementara dan memaknai ruang lingkup, sebab } \\
\text { akibat dan alternatif pemecahan masalah }\end{array}$ \\
\hline $\begin{array}{l}\text { Mengumpulkan, } \\
\text { mengelompokkan data } \\
\text { sebagai bukti hipotesis }\end{array}$ & $\begin{array}{l}\text { Peserta didik mempunyai kecakapan mencari } \\
\text { dan menyusun data, menyajikan data dalam } \\
\text { bentuk diagram, tabel, gambar }\end{array}$ \\
\hline Pembuktian hipotesis & $\begin{array}{l}\text { Peserta didik mampu memiliki kecakapan } \\
\text { menelaah dan membahas data, menghubungkan } \\
\text { dan menghitung, keterampilan mengambil } \\
\text { keputusan dan kesimpulan }\end{array}$ \\
\hline $\begin{array}{l}\text { Menentukan pilihan } \\
\text { penyelesaian }\end{array}$ & $\begin{array}{l}\text { Peserta didik memiliki kecakapan membuat } \\
\text { alternatif penyelesaian , menilai pilihan dengan } \\
\text { memperhitungkan akibat yang terjadi pada setiap } \\
\text { pilihan }\end{array}$ \\
\hline
\end{tabular}

Sumber: John Dawey (W.Gulo, 2002)

Guru melakukan penilaian kegiatan belajar peserta didik sebagai kegiaatan individu atau diskusi kelompok. Instrumen penilaian adalah lembar pengamatan atau observasi. Format penilaian yang harus disiapkan adalah format penilaian diskusi kelompok dan format penilaian laporan hasil diskusi kelompok. Sumber belajar yang dapat digunakan dalam pembelajaran ekonomi adalah kunjungan ke Desa Wisata, Buku Ekonomi. Selain menggunakan video. Sumber belajar desa wisata juga dapat digunakan saat kunjungan. Dengan video pembelajaran desa wisata, koran/majalah tentang ekowisata.

Dengan demikian Pembelajaran berbasis masalah dalam pembelajaran ekonomi meliputi tahap: Merumuskan masalah, Menelaah masalah, Merumuskan hipotesis, Mengumpulkan, mengelompokkan data sebagai bukti hipotesis, Pembuktian hipotesis, Menentukan pilihan penyelesaian. Ekowisata dapat dijadikan sumber belajar. Ekowisata dapat menjadi sumber belajar siswa baik secara langsung maupun tidak langsung. Secara langsung apabila siswa mengamati secara langsung di tempat ekowisata melalui metode field trip/kunjungan. Secara tidak langsung dapat melalui materi ekowisata di buku, LKS atau video. 
Apabila dikaitkan dengan teori dari Sanjaya (Sanjaya, Wina. 2010: 214-215) ciri dalam pembelajaran pemecahan masalah dalam pembelajaran ekonomi yaitu: pertama, pemecahan masalah dalam rangkaian aktivitas pembelajaran baik di kelas maupun luar kelas. Ketika diterpkan di dalam kelas, Peserta didik mengamati video ekowisata dan mampu memberi makna dari video tersebut. Peserta didik aktif berfikir, berkomunikasi, mencari dan mengolah data tentang ekowisata. Ketika berada di luar kelas mereka dapat mengamati obyek secara langsung di desa wisata. Obyek amatan dapat berupa kegiatan ekonomi yang berlangsung. Kedua, mengarahkan aktivitas pembelajaran untuk menyelesaikan masalah ekowisata, apakah ada dalam masalah SDM, teknologi, pemasaran dan sebagainya. Ketiga, pemecahan masalah menggunakan pendekatan berfikir ilmiah yang dilakukan secara empiris dan sistematis pada obyek ekowisata.

\section{SIMPULAN}

Berdasarkan uraian artikel di atas, kesimpulan yang diperoleh adalah permasalahan ekowisata dapat diidentifikasikan sebagai berikut: a) Ekowisata mengedepankan isu konservasi di dalamnya, namun masih ada pelanggaran di lapangan b) Rendahnya partisipasi masyarakat dalam Ekowisata. c) Pengelolaan yang salah. d)Kurang pelibatan lembaga pendidikan formal di sekitar sekolah. Model Pengembangan Ekowisata Berkelanjutan yang disusun berdasarkan penggolongan 4 (empat) Elemen yaitu; (1) Elemen Utama adalah menempatkan isu pembangunan berkelanjutan sebagai visi dan tujuan utama dari pola pengembangan dan pengelolaan wisata, ; (2) Elemen Produk Pariwisata, mewujudkan wisata berbasis masyarakat; (3) Elemen Kriteria, Pemilikan pilar pelestarian lingkungan, pelestarian budaya, pengayaan atraksi, pendidikan berbasis partisipasi, keeratan masyarakat, dan pemberdayaan ekonomi masyarakat lokal (4) Elemen Pendukung, Didukung sepenuhnya oleh seluruh stakeholders yakni: masyarakat, pengunjung, pengelola, sekolah, perguruan tinggi, pemerintah pusat, pemerintah daerah maupun pengusaha pariwisata sebagai. Pembelajaran berbasis masalah dalam pembelajaran ekonomi meliputi tahap: Merumuskan masalah dalam ekowisata, menelaah masalah ekowisata merumuskan hipotesis penyebab masalah ekowisata, mengumpulkan data tentang ekowisata, mengelompokkan data sebagai bukti hipotesis, pembuktian hipotesis, menentukan pilihan penyelesaian. Ekowisata dapat menjadi sumber belajar siswa baik secara langsung maupun tidak langsung.

Dalam penerapannya perlu kerja sama antara berbagai pihak baik pihak sekolah maupun pihak di pengelola ekowisata. Hendaknya ada kesinambungan antara pembelajaran di kelas dan desa wisata. Subtansi ekowisata hendaknya dapat diintegrasikan pada pembelajaran yang lain seperti geografi, sejarah, sosiologi dan PPKN, sehingga pelajar kelah dapat memiliki pemahaman yang benar tentang ekowisata dan pada akhirnya dapat melanjutkan usaha tersebut untuk kesejahteraan dirinya dan orang di sekitarnya. 


\section{DAFTAR PUSTAKA}

Awang,S.A. dkk. (2009). Konsep Ekonomi Kerakyatan dan Aplikasinya pada Sektor Kehutanan -disampaikan dalam diskusi 6 Juni 2009 Kepala Pusat Studi Ekonomi Kerakyatan UGM, Pengajar FKT-UGM Yogyakarta, Diakses http://ekonomikerakyatan.ugm.ac.id/seminar-bulanan/

Boedirachminarni, A., \& Suliswanto, S. W. (2013). Pengembangan Ekowisata di Kabupaten Malang. Jurnal Ekonomi Pembangunan, 15(01), 105-116.

Fandeli, C. (2000). Pengertian dan konsep dasar ekowisata. Yogyakarta, Fakultas Kehutanan UGM. Diakses pada https://d1wqtxts1xzle7.cloudfront.net/32377091/konsep ekowisata.pdf?1385142455=\&responsecontentdisposition=inline\%3B+filename\%3DEkowisat a_PENGERTIAN_DAN_KONSEP_DASAR_EK.pdf\&Expires $=1594469976 \&$ Signature $=J b l r$ 3mApMFI4cN1 v0bx5hqyg4tUEbU7CRnRZGPjwRjcpEL35Ewipc1wg3YEjKkD AzU9iy06 Txmq6SUQU3u8YTOIpqDEn6eBXNWS4kvTotyd8OjCeG2cxuo2qi20HKCXPQIXNQb26z XYZHjaiIeFUGM6sZDglPmuHx 86qvRy1xQ13O3 wOHjWgO kYvRxa6y E3hjVN4I6Gmq sDM4dNUnXDhIX4MuIFaa1Cfa8dD7P17Rrtnowo6yDBfozxeg99XU3K6fz8nMImxjwmRxkhAD1W46G3R6DAB8kX4dvtiil56GtlWmMcHCDlkDdVt7naQKieEUJ3wE7LjnQ \&Key-Pair-Id=APKAJLOHF5GGSLRBV4ZA

Fry, H., Ketteridge, S., dan Marshall, S. (2013). Handbook Teaching and Learning. Riau: Zanafa Publishing.

Haryadi, Toto \& Aripin. 2015. Melatih Kecerdasan Kognitig, Afektif, dan Psikomotorik Anak Sekolah Dasar Melalui Perancangan Game Simulasi "Warungku". Jurnal Desain Komunikasi Visual \& Multimedia, 01(02), pp. 39-50.

Haryanto, Joko Tri. 2014. Model Pengembangan Ekowisata Dalam Mendukung Kemandirian Ekonomi Daerah Studi Kasus Provinsi DIY. Kawistara, 4(3), 271-286.

Hermansyah, H., \& Sunaryo, B. (2018). Pengembangan Marine Ecotourism "Bontang Kuala" Melalui Community Development PT Badak NGL. Economics Development Analysis Journal, 5(1), 1-15.

Hidayati. 2014. Pendekatan Inquiry, Problem Solving, dan Sains Teknologi dan Masyarakat (STM). Bandung: Universitas Pendidikan Indonesia.

Majid, Abdul. (2005). Perencanaan Pembelajaran. Bandung: Rosda Karya

Maryati, Iyam. 2018. Penerapan Model Pembelajaran Berbasis Masalah pada Materi Pola Bilangan di Kelas VII Sekolah Menengah Pertama. Jurnal Mosharafa, 7(1), 63-73.

Poerwanto, Endy. 2016. Demi MEA, Desa Wisata Yogyakarta Berbenah. Diakses pada https://bisniswisata.co.id/demi-mea-desa-wisata-yogyakarta-berbenah/.

Rosyidi, S. (2011). Pengantar Teori Ekonomi Pendekatan Kepada Teori Ekonomi Mikro dan Makro. Jakarta: Rajawali Pers.

Satria, Dias. 2009. Strategi Pengembangan Ekowisata Berbasis Ekonomi Lokal Dalam Rangka Program Pengentasan Kemiskinan. Journal of Indonesian Applied Economics, 3(1), 37-47.

Sanjaya, Wina. 2010. Strategi Pembelajaran Berorientasi Standar Proses Pendidikan. Jakarta: Kencana Prenada Media

Samuelson, P.A,1976. Economics.tenth edition. New York: McGraw Hill-Book Company

Setiawan, D. (2020). Strategi Pengembangan Ekonomi Masyarakat Berbasis Wisata Di Wilayah Makam Bung Karno (Studi di Kelurahan Sentul Kota Blitar). REVITALISASI, 7(4), 319-336.

Sutjipto. 2016. Pentingnya Pelatihan Kurikulum 2013 Bagi Guru (The Importance of Training Curriculum 2013 for Teachers). Jurnal Pendidikan dan Kebudayaan, 01(02), 235-260.

Gulo, W. 2002. Strategi Belajar Mengajar. Jakarta: Grassindo 
Yudhiyati, Ratna. 2020. Pendidikan Akuntansi Forensik di Indonesia: Sebuah Kajian Literatur. Jurnal Pendidikan Akuntansi Indonesia, 18(01), 60-68.

Yulianto, A., \& Yulianto, A. (2006). Peningkatan Hasil Belajar Siswa dalam Mata Pelajaran Ekonomi melalui Pendekatan Pembelajaran Kontekstual (Contextual Teaching and Learning) pada SMA Negeri 11 Semarang. Dinamika Pendidikan, 1(2), 142-167.

Zahroh, Fatim. 2017. Pentingnya Pendidikan Karakter dalam Dunia Pendidikan. Diakses pada https://www.kompasiana.com/fatiiim/590ff69fa5afbd8508fef994/pentingnya-pendidikankarakter-dalam-duniapendidikan\#: :text=Pendidikan\%20karakter\%20adalah\%20 pendidikan\%20yang,agar\%20menjadi\%20pribadi\%20yang\%20baik. 